\title{
Analysis of A Two-Axis Solar Tracker System: Case Study
}

\author{
https://doi.org/10.3991/ijoe.v17i05.21991 \\ Washington Xavier García-Quilachamin $\left({ }^{\square}\right)$ \\ Universidad Laica Eloy Alfaro de Manabí, Manta, Ecuador \\ profegarcia501@gmail.com \\ Julieta Evangelina Sanchez-Cano \\ Universidad Juárez del Estado de Durango, Dgo, México \\ Jorge Herrera-Tapia, Edisson Javier Velesaca-Zambrano \\ Universidad Laica Eloy Alfaro de Manabí, Manta, Ecuador
}

\begin{abstract}
The environmental pollution that arose from the 20th century has led to the search for clean and renewable energies, so this research aims to determine the efficiency of a two-axis solar tracker system, through the analysis of the data obtained. In view of the fact that it remains perpendicular to the solar rays for a longer time, which automatically moves to the point where the radiation source is. Mathematical models were considered for this study based on parameters of time, voltage, solar radiation, temperature, ultraviolet radiation, inclination angles, and cardinal points, to which the panel was directed during the test days. The efficiency given by the solar panel was obtained as $15.34 \%$ on average among monocrystalline silicon solar panels. It was concluded with the analysis of the most relevant data that are, the voltage, the solar radiation, and the angle of inclination to determine with these three parameters if the dual-axis tracker system had an excellent capture of solar radiation in the test days, in order to make the collection and production of solar energy more efficient.
\end{abstract}

Keywords - Two-axis solar tracker, radiation capture, energy efficiency, solar radiation

\section{Introduction}

The author [1] states that the technology in recent years has led human beings to search for clean and renewable energies, that have high energy efficiency and that at the same time it is not so difficult to generate; solar energy is ideal and contributes to replacing fossil energy, since much of the electrical energy used in the world is generated through the use of fossil fuels in accordance with [2] and [3]. The energies from non-conventional renewable sources that have been most implemented are solar, which will be emphasized in this study, taking into account [4].

The solar energy radiated in one day on Earth is equal to the energy that humans produce in an entire year based on [5]. According to [6], the sun's energy leaves its core 
through a process called nuclear fusion and takes a little over eight minutes to travel 93 million miles to Earth. Solar energy travels at the speed of light at 186,000 miles per second, so from the position of [4], the energy captured by the Earth is a small part of that radiated by the sun, but that is more than enough to meet energy needs.

From the point of view of [7] and [8], photovoltaic solar energy is responsible for producing electricity from solar radiation, using a technology based on the photovoltaic effect. Therefore, when the radiation falls on one of the faces of the photoelectric cell, an electric potential difference is produced between both faces that causes the electrons to jump, thus generating an electric current.

According to [9], [10] and [11] photovoltaic systems constitute the application of solar energy that has experienced the greatest expansion in recent years, since one of the most energy efficient technologies is photovoltaic solar energy, considering [12]. The authors [1] and [13], are also considered, who state that photovoltaic systems influence their cells when photons of light are converted into electrical energy and when solar radiation affects an area of the photovoltaic material, the photons will cross the surface transforming energy.

The authors [14] and [15] are considered, who state that energy through solar panels allows electricity to be produced in the place where it is required, reducing the need for energy transport, thereby giving a positive energy balance in its entirety. In addition, the use of mobile photovoltaic systems represents a saving in electrical energy costs, which is generated many times by the consumption of fossil fuels as indicated by the authors [16]. Thus, the photovoltaic solar energy is also a renewable energy that allows reducing greenhouse gases in addition to contributing to other benefits for the environment, according to [4]. According to [17] state that currently there are photovoltaic systems that allow the capture of radiation at all times and that they are known as solar tracker systems, which remain perpendicular to the sun's rays for much longer. From the point of view of [7] and [18], the use of these mobile photovoltaic systems has increased and consequently brings more benefits by taking more advantage of solar energy throughout the day. So according to [19], these are a good option to improve the long-term cost-benefit ratio of these systems.

The author [20] mentions that mobile photovoltaic systems can be structured in one or two axes. Taking into account [21], single-axis systems have a degree of freedom which increases the uptake of direct solar radiation more than a fixed system. On the other hand, according to [22] the two-axis systems, which will be emphasized, have two degrees of freedom and these helps to increase the capture of direct solar radiation by up to $33 \%$.

Based on [23], the two most common orientations for a system that follows the path of the sun to achieve the highest possible performance of solar radiation that falls on a specific surface or point are: on one-axis to follow the sun from east to west and on two axes that guarantee to always follow the sun directly. According to [24], they state that the two-axis system is the best to take full advantage of the capture of direct solar radiation.

This research aims to determine the efficiency of a two-axis automatic mobile so-lar panel system through the analysis of the data obtained in view of the fact that it remains perpendicular to the solar rays for a longer time. Therefore, for this study mathematical 
models based on parameters such as time, voltage, solar radiation, temperature, ultraviolet radiation, inclination angles and cardinal points are considered, to which the panel was directed during the test days.

\section{Methodology}

Considering that the objective of this study is to analyze a Two-axis solar tracker system, an experimental design that was applied through a prototype was used. This study will be designed under the methodological quantitative approach since data collection that will be obtained and analyzed. The data collection technique that was carried out in this study was based on mathematical models, instruments, and pro-grams to calculate different sections that will be necessary in this study.

The mathematical models are the solar radiation according to the author [25], the ultraviolet radiation reported [26], the equation of peak solar hours from the point of view of [27] and the equation of the panel performance solar according to [28].

\section{$2.1 \quad$ Tools used}

For the purpose of this study, tools and software were used for data collection such as for the design of the structure and the design of the prototype circuit. Among which was used a multimeter, a digital compass, a digital level, a software on the forecast to know temperature and radiation, PVGIS software. A small solar panel, an Arduino Uno board, 4 photoresistors, $410 \mathrm{k} \Omega$ resistors, 2 servomotors, a breadboard, and Tinkercad software were also used to design the structure and circuit of the prototype.

\section{$2.2 \quad$ Framework}

A framework was developed in reference to the objective of this study on a two-axis photovoltaic system, for which based on the algorithm used and as a function the monitoring of solar radiation during the day, allows the solar panel to be during the day perpendicular to the sun`s rays. The process is represented in Figure 1 describing efficient radiation capture, as the sun's rays would point directly at the solar panel.

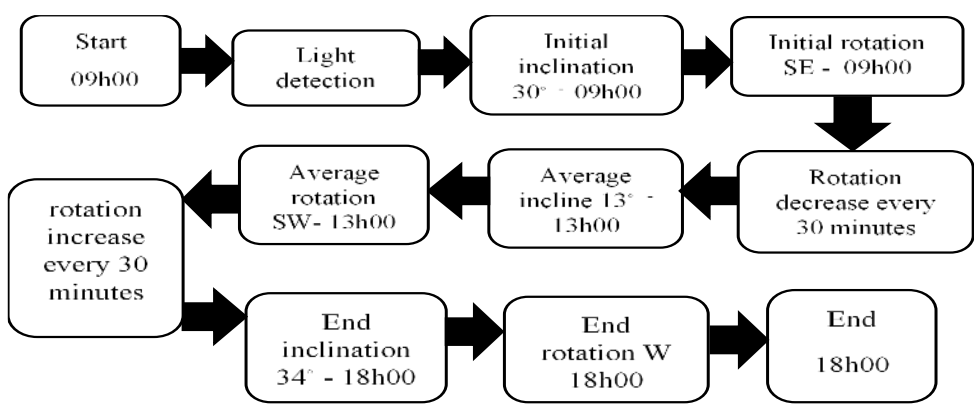

Fig. 1. System tilt and rotation process during the day 


\subsection{Solar modules}

To achieve an efficient photovoltaic system it also depends on the type of solar module used according to [29]. The author [9] states that there are three fundamental types of solar modules that are made of silicon and that they are shown in Table 1.

Table 1. Solar panels with their respective yields

\begin{tabular}{|l|c|c|}
\hline \multicolumn{1}{|c|}{ Solar Panel } & & Performance in commercial modules \\
\hline Monocrystalline silicon & Maximum 24\% & $15 \%-18 \%$ \\
\hline Polycrystalline silicon & Maximum 20\% & $12-14 \%$ \\
\hline Amorphous silicon & Maximum 10\% & $8-10 \%$ \\
\hline
\end{tabular}

The monocrystalline silicon module is the one used in the prototype of this study in order to have a good capture of solar radiation on par with the system.

\subsection{Design of the double axis prototype structure}

Figure 2 shows the design of the prototype structure of the two-axis system of this study, which was carried out through the Tinkercad software. The tilt axis would be linked to the vertical servomotor and the round part of the structure would give the panel rotation with the horizontal servomotor.

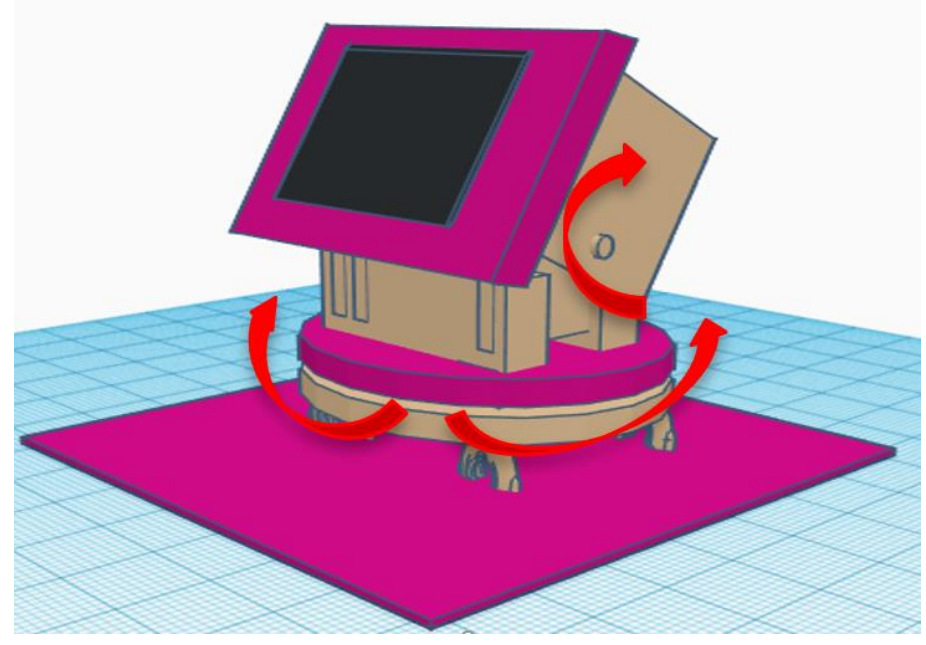

Fig. 2. Structure of the two-axis system prototype

The tilt axis would be linked to the vertical servomotor and the round part of the structure would give the panel rotation with the horizontal servomotor. 


\subsection{Circuit design for the automatic system}

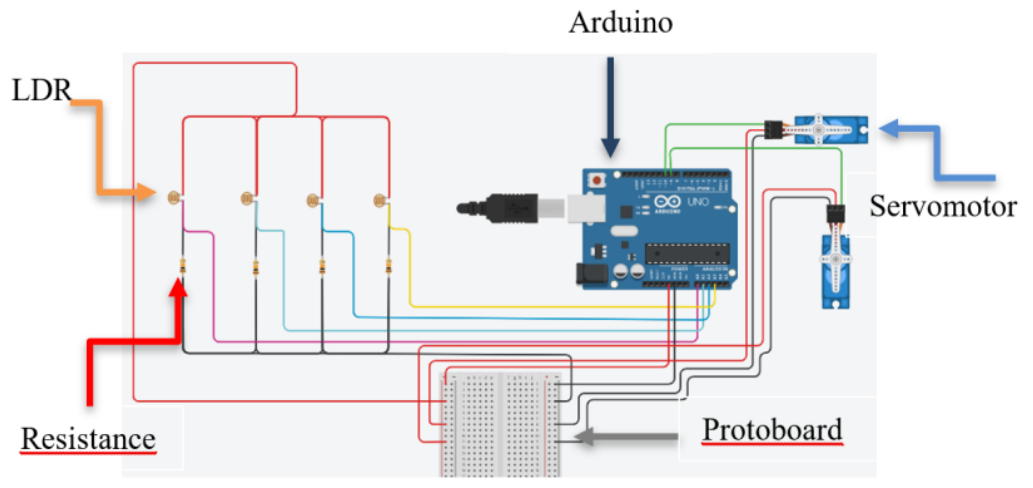

Fig. 3. Prototype solar

The programming and code developed in this study was carried out on Arduino, which allows the two-axis prototype to follow the light and thus be perpendicular to the solar rays all the time.

\subsection{Prototype of two-axis solar tracker system}

In the prototype designed and visualized in Figure 4, each photoresistor is placed in one corner of the panel, which are each linked with a $10 \mathrm{k} \Omega$ resistor. The photoresistors are linked to 4 analog pins and the servomotors to two digital pins of the Arduino. The sources and grounds of the circuit are connected to the breadboard. It should be noted that the panel automatically moves according to position of the sun.

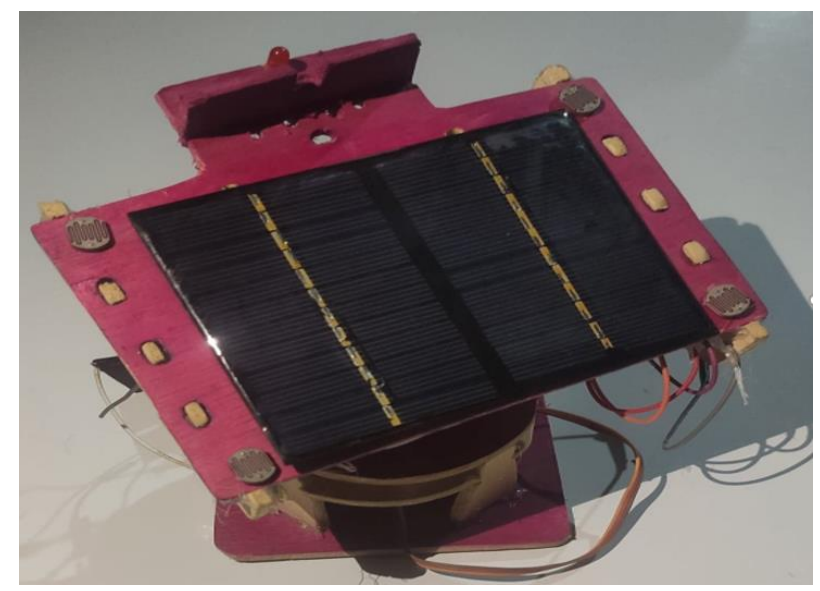

Fig. 4. Two-axis solar tracker system prototype (automatic) 


\subsection{Data description}

The data collection was based on different factors which influenced the voltage generated by the solar panel. For this collection, the solar panel was tested from 9:00 a.m. Until 6:00 p.m. in Manta city, Ecuador, since 9:00 a.m. was when the solar radiation began to increase and at 6:00 p.m. was when the sky was completely cloudy. This process was carried out during 5 days without any interruption, and in 30-minute intervals data were collected on voltage, solar radiation, temperature, ultraviolet radiation, inclination angles, direction taken by the panel and atmospheric condition. The data obtained was placed in an Excel database, which was averaged. In addition, the solar panel was tested to charge a completely discharged battery which took 30 and a half hours to charge with a solar panel of 1.5 watts.

\subsection{Mathematical equations and models}

To obtain data on peak solar hours, the following equations is needed (1)

$$
H S P=\frac{E}{d}
$$

Where:

HSP: These are peak solar hours, E: It is the average irradiance of a month and d: They are de numbers that must be calculated during the month.

Solar radiation is calculated by integrating the intensity $I_{0}$ between the angles $\omega_{0}$ sunrise and sunset. The following mathematical model (2) is with which solar radiation could be calculated:

$$
H_{0}=\int_{-\bar{\omega} 0}^{\omega 0} I_{0} * \operatorname{sen} A * d\left(\frac{24 * 3600}{2 \pi} \bar{\omega}\right)
$$

Where:

$H_{0}$ : It is the solar radiation from the horizontal on Earth $\omega 0$ : It is the angle of the ortho which is the one that crosses the plane of the horizon and passes to the visible hemisphere on Earth, $-\bar{\omega} 0$ : It is the angle of sunset which occurs when the Earth crosses the plane of the horizon and passes from the visible to the non-visible hemisphere, $I_{0}$ : It is the intensity of the solar energy emitted towards the Earth, sen $A$ : It is the angle of the area with respect to the sun in which the radiation is to be taken, $\bar{\omega}$ : It is the movement of the sun on the earth's horizontal, and $d$ : It is the differential of the integral.

Also, in order to calculate the ultraviolet radiation index, the following mathematical model is needed (3):

$$
I_{u v}=K_{e r} \int_{250 \mathrm{~nm}}^{400 \mathrm{~m}} E_{\lambda} * S_{e r} \lambda d \lambda
$$

Where: 
$I_{u v}$ : It is the index of ultraviolet radiation emitted by the sun, $K_{e r}$ : it is a constant which is $40 \mathrm{~m}^{2} / \mathrm{W}, E_{\lambda}$ : It is the solar spectral irradiance expressed in $\mathrm{W} /\left(\mathrm{m}^{2} * \mathrm{~nm}\right), S_{e r}$ : It is the reference action spectrum for the erythema, $\lambda$ : It is the length of the radiation wave, and $d \lambda$ : It is the wavelength difference used in the integration.

To calculate the performance or efficiency of the panel the following equation is needed (4):

$$
\eta=\frac{P \max }{A * E} * 100
$$

Where:

$\eta$ : Panel solar yield in percentage (\%), Pmax: The maximum power of the solar panel, A: Solar panel area y E: Maximum solar irradiation captured by the solar panel.

\section{Results}

\subsection{Average irradiation and peak solar hours in Manta}

To obtain the irradiation data PVGIS was used, considering that geographic data can be calculated from any part of the world and for peak solar hours, the equation (1) was used. These data are shown in Table 2. The city of Manta is in Ecuador, located practically in the middle of the world.

Table 2. Average data obtained on irradiation and HSP in Manta-Ecuador

\begin{tabular}{|l|c|c|}
\hline \multicolumn{1}{|c|}{ Month } & Daily irradiation $\left(\mathbf{W} / \mathbf{m}^{\mathbf{2}}\right)$ & HSP \\
\hline January & 132,03 & 4,26 \\
\hline February & 126,88 & 4,53 \\
\hline March & 164,91 & 5,32 \\
\hline April & 160,97 & 5,37 \\
\hline May & 143,99 & 4,64 \\
\hline June & 164,4 & 5,48 \\
\hline July & 150,31 & 4,85 \\
\hline august & 174,88 & 5,64 \\
\hline September & 168,66 & 5,62 \\
\hline October & 148,91 & 4,8 \\
\hline November & 136,62 & 4,55 \\
\hline December & 129,69 & 4,18 \\
\hline
\end{tabular}

\subsection{Data obtained with the prototype}

Obtaining the results of the prototype was divided into 4 phases:

1. Related to the voltage generated by the solar panel and other parameters, 2 . In relation to the angle of inclination and direction taken by the panel at different times of the day automatically, 3. It is related to the percentage charged of 12 Volt battery bye the solar panel, and 4. It is related to the efficiency of the solar panel used. 
Phase 1, average voltage, $\mathrm{KW} / \mathrm{m} 2$ radiation, temperature, and $\mathrm{UV}$ radiation: The results shown in Table 3 are the average of data collected for 5 days, of voltage, solar radiation, temperature, and ultraviolet radiation. To obtain the voltages, a multimeter was needed, which was connected in parallel with our solar panel.

To facilitate the obtaining of solar radiation and ultraviolet radiation, in this study a solar measurement software was used that instantly showed us the radiation level in the city of Manta, Ecuador. Using this software, the temperature shown by the forecast was also obtained.

Figure 5 represents the average results obtained each day from the voltage generated by the solar panel. It can be seen that day 3 was the day in which the solar panel had a voltage deficiency and on day 5 it was de opposite.

On the day 3 the voltage was low due to the atmospheric condition because was a cloudy day and therefore direct solar radiation was low, which produced that mini-mum average voltage, and on this day the panel generated the lowest voltage record-ed that was 8.84 volts at 6:00 p.m.

Day 5 as seen in Figure 5 was the day in which the panel generated a higher voltage because was a sunny day, and even that day the solar panel generated the highest voltage obtained which was 13,31 volts at 1:00 p.m.

Table 3. Average results obtained for 5 days.

\begin{tabular}{|c|c|c|c|c|}
\hline Hour & Voltage (V) & Temperature $\left({ }^{\circ} \mathrm{C}\right)$ & $\begin{array}{c}\text { Radia- } \\
\operatorname{tion}\left(K / W^{*} \mathbf{m}^{2}\right)\end{array}$ & Radiation (UV) \\
\hline 9:00 a. m. & 12,11 & 23,2 & 0,33 & 1,7 \\
\hline 9:30 a. m. & 12,48 & 24,2 & 0,43 & 3,6 \\
\hline 10:00 a. m. & 12,73 & 24,8 & 0,51 & 4,9 \\
\hline 10:30 a. m. & 12,74 & 25,6 & 0,55 & 7,6 \\
\hline 11:00 a. m. & 12,60 & 25,8 & 0,59 & 8,9 \\
\hline 11:30 a. m. & 12,58 & 26,6 & 0,62 & 8,1 \\
\hline 12:00 p. m. & 12,60 & 26,6 & 0,65 & 8,9 \\
\hline 12:30 p. m. & 12,67 & 27,2 & 0,66 & 8,8 \\
\hline 1:00 p. m. & 12,76 & 27,2 & 0,6 & 9,9 \\
\hline 1:30 p. m. & 12,51 & 27,4 & 0,62 & 9,3 \\
\hline 2:00 p. m. & 12,64 & 27,4 & 0,59 & 7,6 \\
\hline 2:30 p. m. & 12,62 & 27,2 & 0,58 & 6,2 \\
\hline 3:00 p. m. & 12,59 & 27,2 & 0,5 & 5,5 \\
\hline 3:30 p. m. & 12,44 & 27,2 & 0,41 & 4,3 \\
\hline 4:00 p. m. & 12,30 & 26,4 & 0,31 & 2,7 \\
\hline 4:30 p. m. & 12,28 & 25,8 & 0,24 & 1,6 \\
\hline 5:00 p. m. & 11,61 & 25,4 & 0,15 & 0,9 \\
\hline 5:30 p. m. & 11,15 & 25 & 0,07 & 0,4 \\
\hline 6:00 p. m. & 10,05 & 24,6 & 0,03 & 0,1 \\
\hline
\end{tabular}




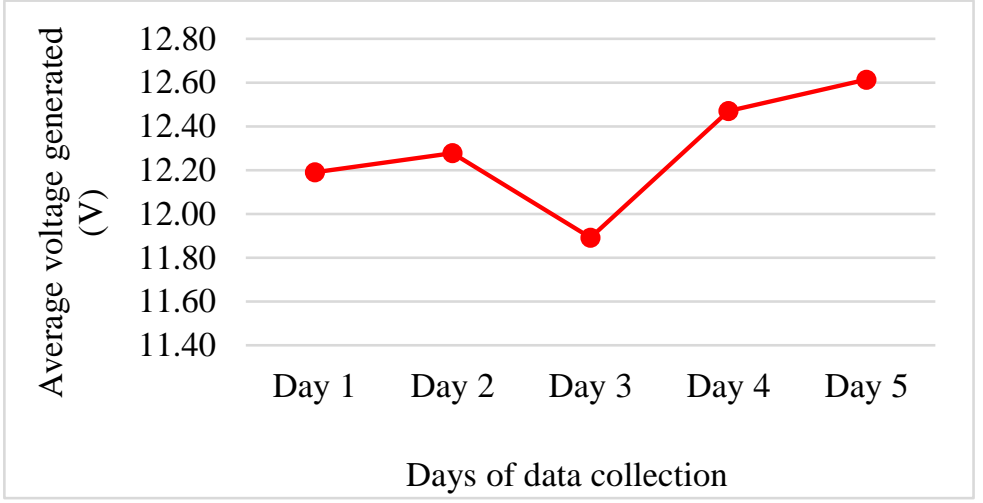

Fig. 5. Average results of voltage obtained each day

Phase 2, average tilt angle, cardinal point taken by the panel automatically and atmospheric condition: The data obtained are shown in Table 4, considering that to calculate the exact degree and direction of the panel on the surface, an inclinometer and digital compass were needed. In atmospheric conditions the abbreviations are described: PN: Partially cloudy, P C: Partially clear, T D: Totally clear y T N: Totally cloudy

Table 4. Average results of data obtained during the 5 days

\begin{tabular}{|c|c|c|c|}
\hline Time (m) & Angle ( $\left.{ }^{\circ}\right)$ & Direction & Atmospheric condition \\
\hline 9:00 a. m. & 30 & Southeast & P N \\
\hline $9: 30$ a. $\mathrm{m}$. & 28 & Southeast & P N \\
\hline 10:00 a. m. & 25 & Southeast & $\mathrm{PC}$ \\
\hline $10: 30$ a. $\mathrm{m}$. & 23 & Southeast & $\mathrm{PC}$ \\
\hline 11:00 a. m. & 20 & Southeast & T C \\
\hline $11: 30$ a. m. & 19 & Southeast & $\mathrm{PC}$ \\
\hline 12:00 p. m. & 16 & South & $\mathrm{PN}$ \\
\hline $12: 30$ p. m. & 15 & South & P N \\
\hline 1:00 p. m. & 13 & Southeast & $\mathrm{PC}$ \\
\hline 1:30 p. m. & 13 & Southeast & $\mathrm{PN}$ \\
\hline 2:00 p. m. & 13 & Southeast & P N \\
\hline 2:30 p. m. & 14 & Southeast & $\mathrm{PC}$ \\
\hline 3:00 p. m. & 16 & Southeast & $\mathrm{PC}$ \\
\hline 3:30 p. m. & 19 & Southeast & $\mathrm{P} \mathrm{N}$ \\
\hline 4:00 p. m. & 21 & West & $\mathrm{P} \mathrm{N}$ \\
\hline 4:30 p. m. & 23 & West & $\mathrm{P} \mathrm{N}$ \\
\hline 5:00 p. m. & 27 & West & $\mathrm{PN}$ \\
\hline 5:30 p. m. & 30 & West & T N \\
\hline 6:00 p. m. & 34 & West & T N \\
\hline
\end{tabular}

Also, Figure 6 represents the statistics of the data regarding the angle that the prototype of mobile solar panel takes according to the time in which the data was collected. 


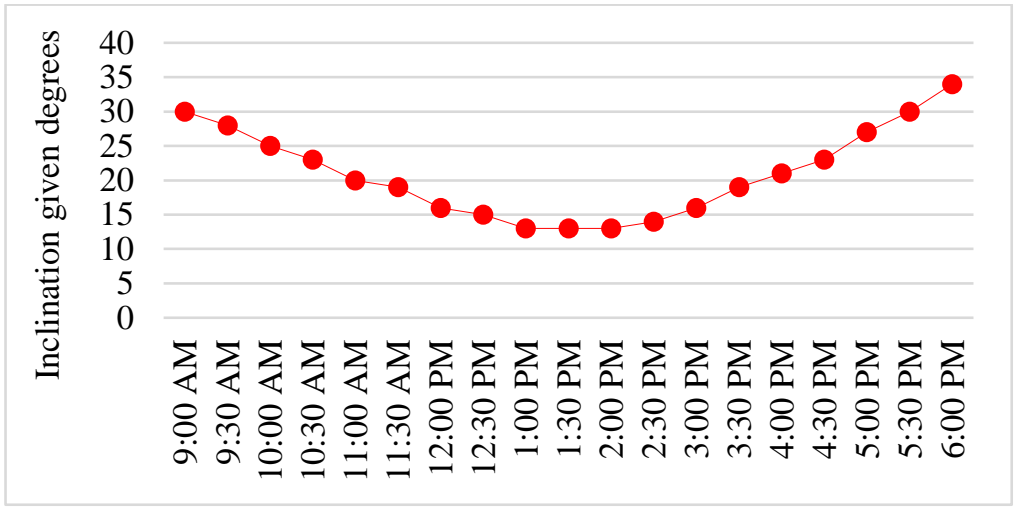

Fig. 6. Variation of the inclination angles taken by the mobile panel during the day

Phase 3, data obtained from a 12V battery charged by the solar panel: In this section, a totally discharged $12 \mathrm{~V}$ battery was chosen, and it was charged with the solar panel used as prototype in this research, while it was charging, the approximate percentage of the battery charge was measured.

Table 5 shows the percentage of charge related to the voltage on the $12 \mathrm{~V}$ battery. It should be noted that the percentage in $12 \mathrm{~V}$ batteries will always be higher, that is, a new $12 \mathrm{~V}$ battery can have up to $13 \mathrm{~V}$.

Table 5. Percentage of charge of a $12 \mathrm{v}$ battery in relation to voltage

\begin{tabular}{|c|c|}
\hline Percentage (\%) & Battery voltage (V) \\
\hline 100 & $\mathrm{~V}>12,90$ \\
\hline 90 & 12,7 \\
\hline 80 & 12,5 \\
\hline 70 & 12,3 \\
\hline 60 & 12,15 \\
\hline 50 & 12,05 \\
\hline 40 & 11,95 \\
\hline 30 & 11,81 \\
\hline 20 & 11,66 \\
\hline 10 & 11,51 \\
\hline 0 & $\mathrm{~V}>10,5$ \\
\hline
\end{tabular}

Table 6 shows the data obtained when the solar panel was feeding the $12 \mathrm{~V}$ battery, which at the beginning was totally discharged, the percentage of charged battery is also shown based on Table 4, during the 3 and a half days that it took load. 
Table 6. Results of the battery charging process

\begin{tabular}{|c|c|c|c|c|c|c|c|c|c|}
\hline Hour & $\begin{array}{c}\text { Charging } \\
\text { Voltage } \\
\text { (V) }\end{array}$ & $\begin{array}{c}\text { Voltage } \\
\text { charged } \\
\text { on day 1 }\end{array}$ & $\begin{array}{c}\text { Percen- } \\
\text { tage } \\
\text { charged } \\
\text { on day 1 }\end{array}$ & $\begin{array}{c}\text { Voltage } \\
\text { charged } \\
\text { on day 2 }\end{array}$ & $\begin{array}{c}\text { Percen- } \\
\text { tage } \\
\text { charged } \\
\text { on day 2 }\end{array}$ & $\begin{array}{c}\text { Voltage } \\
\text { charged } \\
\text { on day 3 }\end{array}$ & $\begin{array}{c}\text { Percen- } \\
\text { tage } \\
\text { charged } \\
\text { on day 3 }\end{array}$ & $\begin{array}{c}\text { Voltage } \\
\text { charged } \\
\text { on day 4 }\end{array}$ & $\begin{array}{c}\text { Percen- } \\
\text { tage } \\
\text { charged } \\
\text { on day 4 }\end{array}$ \\
\hline 9h00 & 12,04 & 1,75 & 0 & 6,77 & 0 & 10,79 & 2,9 & 12,43 & 76,3 \\
\hline $9 \mathrm{~h} 30$ & 12,42 & 2,23 & 0 & 7,08 & 0 & 10,88 & 3,8 & 12,43 & 76,3 \\
\hline $10 \mathrm{~h} 00$ & 12,75 & 2,75 & 0 & 7,74 & 0 & 11,08 & 5,8 & 12,49 & 79,9 \\
\hline $10 \mathrm{~h} 30$ & 12,75 & 3,05 & 0 & 8,22 & 0 & 11,17 & 6,7 & 12,61 & 85,1 \\
\hline $11 \mathrm{~h} 00$ & 12,62 & 3,14 & 0 & 8,46 & 0 & 11,34 & 8,4 & 12,73 & 90,3 \\
\hline $11 \mathrm{~h} 30$ & 12,62 & 3,38 & 0 & 8,71 & 0 & 11,71 & 21,1 & 12,82 & 95,2 \\
\hline $12 \mathrm{~h} 00$ & 12,50 & 3,51 & 0 & 9,05 & 0 & 11,82 & 30,2 & 12,89 & 99,8 \\
\hline $12 \mathrm{~h} 30$ & 12,55 & 3,69 & 0 & 9,38 & 0 & 11,94 & 39,9 & 12,94 & 100 \\
\hline $13 \mathrm{~h} 00$ & 12,63 & 4,18 & 0 & 9,81 & 0 & 11,98 & 43,8 & 12,94 & 100 \\
\hline $13 \mathrm{~h} 30$ & 12,38 & 4,36 & 0 & 9,98 & 0 & 11,98 & 43,8 & 12,94 & 100 \\
\hline $14 \mathrm{~h} 00$ & 12,57 & 5,14 & 0 & 10,15 & 0 & 12,06 & 51,6 & 12,94 & 100 \\
\hline $14 \mathrm{~h} 30$ & 12,54 & 5,93 & 0 & 10,27 & 0 & 12,13 & 58,3 & 12,94 & 100 \\
\hline $15 \mathrm{~h} 00$ & 12,56 & 6,47 & 0 & 10,42 & 0 & 12,16 & 61,6 & 12,94 & 100 \\
\hline $15 \mathrm{~h} 30$ & 12,38 & 6,61 & 0 & 10,55 & 0,05 & 12,21 & 65,2 & 12,94 & 100 \\
\hline $16 \mathrm{~h} 00$ & 12,24 & 6,72 & 0 & 10,61 & 1,1 & 12,30 & 70 & 12,94 & 100 \\
\hline $16 \mathrm{~h} 30$ & 12,23 & 6,79 & 0 & 10,74 & 2,4 & 12,41 & 75,1 & 12,94 & 100 \\
\hline $17 \mathrm{~h} 00$ & 11,44 & 6,79 & 0 & 10,79 & 2,9 & 12,43 & 76,3 & 12,94 & 100 \\
\hline $17 \mathrm{~h} 30$ & 10,93 & 6,79 & 0 & 10,79 & 2,9 & 12,43 & 76,3 & 12,94 & 100 \\
\hline $18 \mathrm{~h} 00$ & 9,81 & 6,79 & 0 & 10,79 & 2,9 & 12,43 & 76,3 & 12,94 & 100 \\
\hline
\end{tabular}

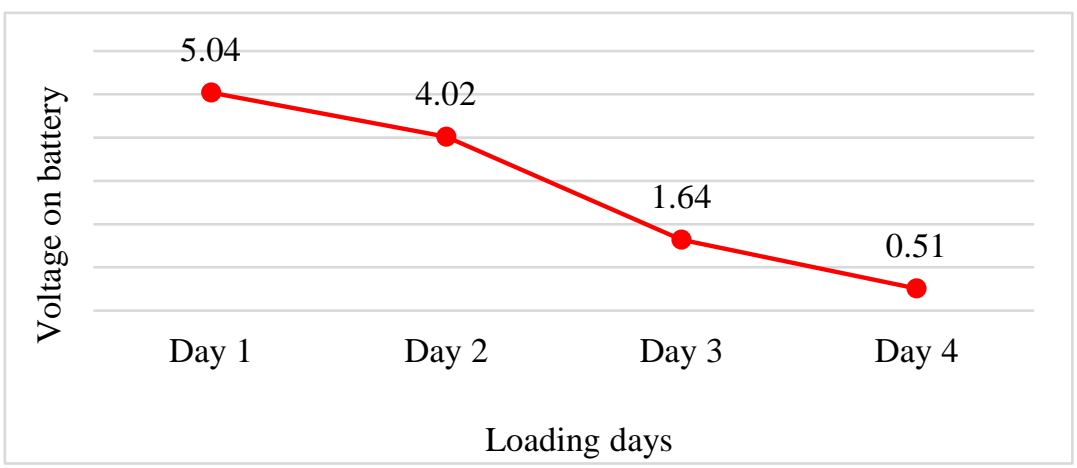

Fig. 7. Voltage that was charged in the battery daily with the solar panel.

In Figure 7, you can see the voltage charged in the battery at the end of the day, during the 4 days while the capture light was taking place, and until the battery was fully charged. It should be emphasized that on day 4 the battery in the middle of the day finished charging.

In Figure 8 you can see the percentage that was charged daily until completing the maximum charge in the battery. 


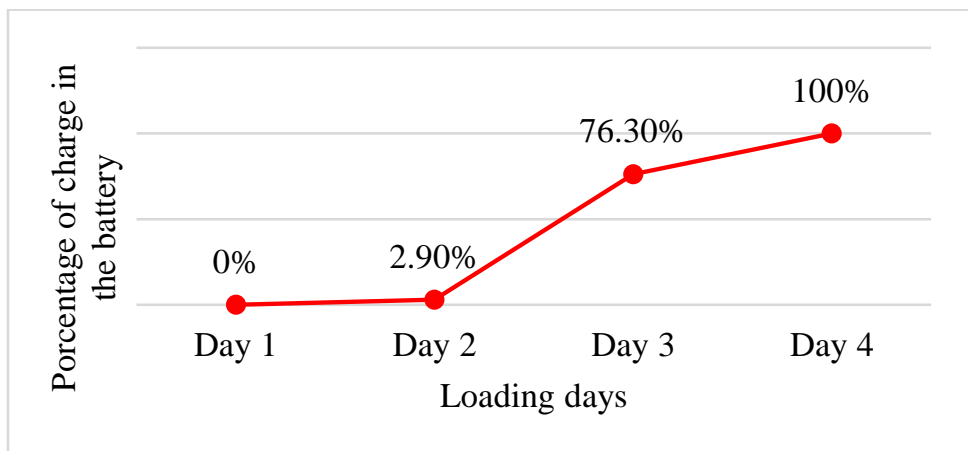

Fig. 8. Battery charge percentage at the end of each day and on day 4 until noon

Phase 4 related to the efficiency of the solar panel used: To calculate the efficiency of the solar panel used, both equation (4) and the necessary data were applied.

Data

Pmax: 1,5W, A: $85 \mathrm{~mm} * 115 \mathrm{~mm}, \mathrm{E}: 1000 \mathrm{~W} / \mathrm{m}^{2}$ Standard

$$
\begin{gathered}
A=9775 \mathrm{~mm}^{2}\left(\frac{1 \mathrm{~m}^{2}}{1000000 \mathrm{~mm}^{2}}\right)=0.009775 \mathrm{~m}^{2} \\
\eta=\frac{1,5 \mathrm{~W}}{0,009775 \mathrm{~m}^{2} * 1000 \mathrm{~W} / \mathrm{m}^{2}} * 100 \\
\eta=15.34 \%
\end{gathered}
$$

In our study the solar panel obtained an efficiency of $15.34 \%$, which is in the average of monocrystalline silicon solar panels.

\section{$4 \quad$ Results Analysis}

The results obtained in this study were made up of 4 aspects, but the results of the voltages, radiation, angles, and the efficiency, in which the results of the voltages, radiation, angles and the efficiency of the solar panel used are highlighted. All these data are necessary to be able to give a final criterion on the use that these two-axis solar tracker systems have. These sections were obtained from the prototype of the two-axis solar tracker system using tools obtained in the city of Manta, Ecuador.

In Figure 9 you can see the values of the voltages, solar radiation, and the angles that the panel had during the day on a partially cloudy day, which refers to Figure 5, in which was noted that on day 3 there was an average voltage lower than the resto of the days. It should be noted that the panel had the same conditions (angles, directions, and location) every day. 


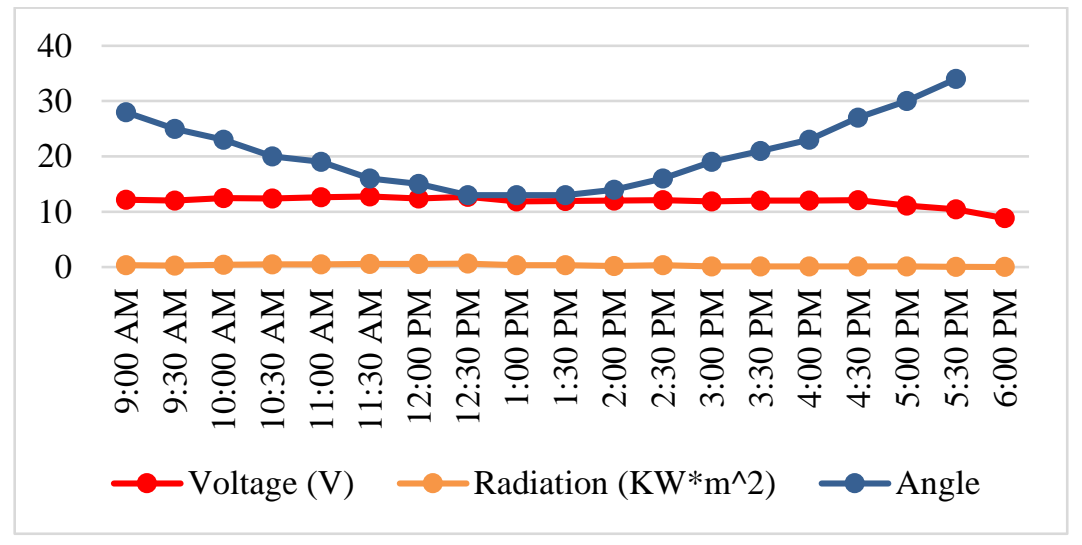

Fig. 9. Results obtained in a partly cloudy day

On the day 3 the voltage was lower due to the less solar radiation that partly cloudy day, which caused the average to drop even more at 6 p.m., on that day the lowest voltage was recorded, which was $8,84 \mathrm{~V}$.

The solar panel generated different voltages depending on the radiation emitted by the sun at that time, it also took some inclination angles depending on the time, and, in Figure 10 you can see the average voltage and the angles that the panel maintained during the day. The voltage depended on the exact direction and tilt that the panel picked up best for direct solar radiation.

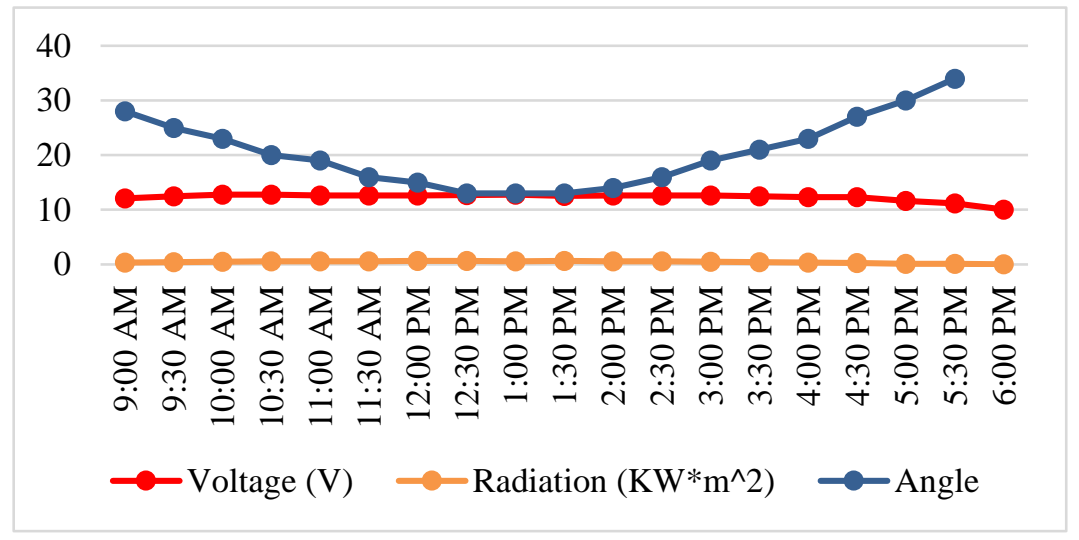

Fig. 10.Average results of voltage, solar radiation, and tilt angle.

In addition to the results shown in figure 10, we have in the two-axis solar tracker used, a performance of efficiency of $15.34 \%$. This panel was made with monocrystalline silicon which made this material have a better solar energy capture, this type of material in solar panels has an average of 15 to $18 \%$ efficiency. Our two-axis solar tracker system is in that efficiency range. 
With the data shown above, it can be stated that the prototype of two-axis solar tracker had a good capture of solar energy in the hours of sun with the highest radiation, because the voltage was always higher than 12 volts, even reaching 13,31 volts in days of higher radiation as can be seen in Figure 11, since the data was taken on a sunny day.

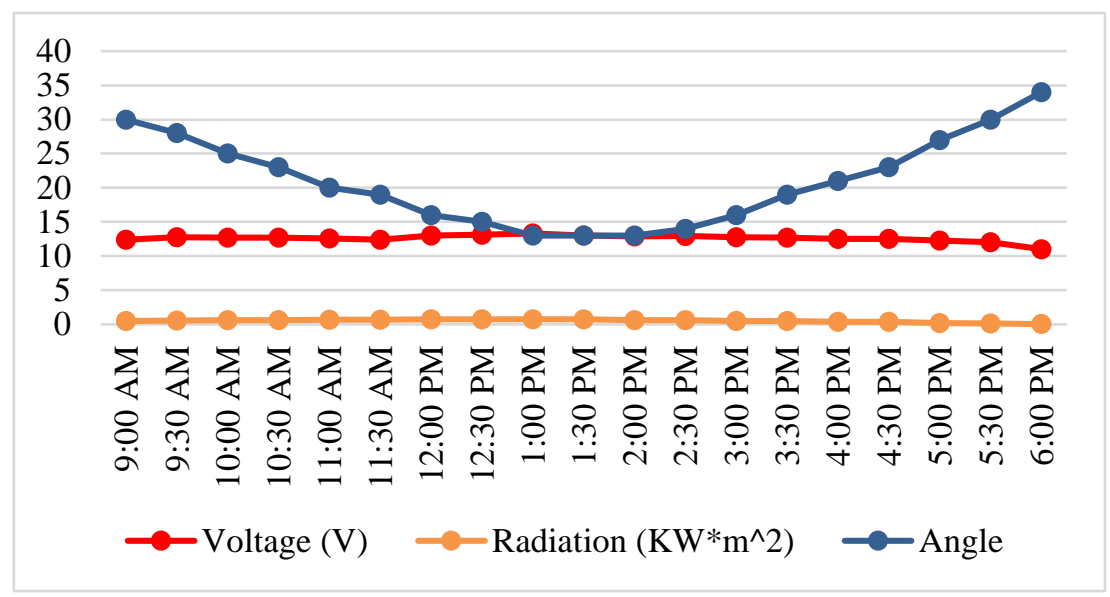

Fig. 11.Results obtained on a sunny day

It is important to highlight that, with the data provided in this research, it is shown that two-axis solar tracker systems are the best solar radiation collector systems, due to the fact that, as observed in Table 3, the two-axis solar prototype (double servomotor) it took a varied inclination and looking towards the cardinal point in which the sun was positioned. These two factors, such as the inclination and direction of the panel, made the solar rays pass perpendicular to the solar panel for much longer, for this reason, these two-axis solar tracker systems are the most efficient in capturing solar radiation, because they take advantage of radiation up to $33 \%$ more than a conventional system.

\section{Conclusion}

This research contributes to the generation of knowledge, it was observed that between the relationship of voltage and radiation, it was possible to verify that in many cases the voltage does not change drastically in relation to an increase or decrease in solar radiation, in any case, the sky should be completely cloudy so that the voltage is less than 12 volts.

In addition, observing the data generated and expressed in the tables related to batteries, we can realize that a solar panel must produce at least 12 volts for it to be functional, otherwise it could not be used if the voltage to be consumed it is 12 or more volts. This panel system carries an algorithm, because the system needs to perform solar tracking and make the servomotors perform the vertical and horizontal turns for the direct capture of solar radiation. 
With the data generated in this research, it is shown that it is advisable to implement two-axis solar tracker systems, because they help to get the most out of a solar panel due to the monitoring that radiation does during the day since it takes advantage of the $33 \%$ more than other conventional panels.

It is also recommended to only implement this type of photovoltaic systems in locations where there are not so many cloudy days, otherwise you could not make good use with any photovoltaic system.x.

\section{References}

[1] V. Vélez Ureta, ““Análisis y evaluación de la captación de energía solar en paneles fotovoltaicos convencionales y con seguimiento solar'.," p. 93, 2017, [Online]. Available: http://repositorio.ucsg.edu.ec/bitstream/3317/9081/1/T-UCSG-PRE-TEC-IEM-113.pdf.

[2] A. A. Tamayo, "Diseño de un Cargador Solar para Atender la Demanda de Carga Eléctrica de Dispositivos Móviles en la Universidad Tecnológica del Perú - Filial Arequipa," 2019, [Online].Available:http://repositrio.utp.edu.pe/hadle/UTP/2295 https://doi.org/10.47300 1978-9962-5599-8-6-14

[3] F. Sapundzhi, "Computer simulation and investigations of the roof mount photovoltaic system,” Int. J. online Biomed. Eng., vol. 15, no. 12, pp. 88-96, 2019, https://doi.org/10.3991/ ijoe.v15i12.10869

[4] J. Crespo and J. Peralta, “"Estudio e implementación de un sistema de micro generación solar fotovoltaico para autoconsumo (caso de estudio considerando la regulación Nro. ARCONEL- 003/18),"” Artic. Ecuador, vol. 1, p. 112, 2019, [Online]. Available: http://dspace.ucuenca.edu.ec/bitstream/123456789/33564/1/Trabajo de Titulación.pdf. https://doi.org/10.20868/upm.thesis.47393

[5] N. Kannan and D. Vakeesan, "Solar energy for future world: - A review," Renewable and Sustainable Energy Reviews, vol. 62. Elsevier Ltd, pp. 1092-1105, Sep. 01, 2016, https://doi.org/10.1016/j.rser.2016.05.022

[6] C. Espejo-Marín and A. E. Aparicio-Guerrero, "La Producción de Electricidad con Energía Solar Fotovoltaica en España en el Siglo XXI.," Rev. Estud. Andaluces, no. 39, pp. 66-93, 2020, https://doi.org/10.12795/rea.2020.i39.04

[7] S. Salamanca-Avila, "Propuesta de diseño de un sistema de energía solar fotovoltaica. Caso de aplicación en la ciudad de Bogotá," Rev. científica, vol. 3, no. 30, p. 263, Sep. 2017, https://doi.org/10.14483/23448350.12213

[8] N. Navarro Enrique, "Estudio comparativo de sistemas solares térmicos y fotovoltaicos," 2018. Accessed: Jan. 07, 2021. [Online]. Available: https://docplayer.es/198979997-Trabajo-final-de-grado.html.

[9] J. Fernández, "Caracterización de módulos fotovoltaicos con dispositivo portátil," U carlos III Madrid, pp. 1-156, 2016, [Online]. Available: https://e-archivo.uc3m.es/bitstream/handle/10016/6037/PFC_Julio_Fernandez_Ferichola.pdf? sequence=1\&isAllowed=y.

[10] D. Assante and M. Tronconi, "Photovoltaic system as a remote didactic laboratory for electrical engineering courses," Int. J. Online Eng., vol. 11, no. 4, pp. 39-46, 2015, https://doi.org/10.3991/ijoe.v11i4.4651

[11] W. Wenxing, "Remote monitoring system for a photovoltaic power substation," Int. J. Online Eng., vol. 11, no. 1, pp. 10-12, 2015, https://doi.org/10.3991/ijoe.v11i1. 3923

[12] A. García and L. Peñuela, "Diseño e Implementación De Un Sistema De Paneles Solares Como Prueba Piloto Para Suministro Energético De Dispositivos Móviles, En La 
Universidad Santo Tomás, Sede Villavicencio Campus Loma Linda," vol. 8, no. 5, p. 81, 2019, [Online]. Available: https://repository.usta.edu.co/bitstream/handle/11634/17565/2019alexandragarcia? sequence $=1 \&$ isAllowed $=\mathrm{y}$. https://doi.org/10.15332/tg.pre.2020.00225

[13] R. Hernández Gallegos, “Análisis de Factibilidad para la Instalación de un-Sistema de Energía Limpia Mediante Celdas Fotovoltaicas para la Alimentación Eléctrica del Edificio 4 en el ITSLV.," CIATEQ, p. 85, 2017, Accessed: Jan. 07, 2021. [Online]. Available: https://ciateq.repositorioinstitucional.mx/jspui/bitstream/1020/97/1/HernandezGallegosRodolfo MMANAV 2017.pdf. https://doi.org/10.26439/ulima.tesis/11574

[14] A. Arena and G. N. Baron, "Diseño De Sistema Fotovoltaico Bifuncional Integrado a Edificio," no. May 2020, 2014.

[15] L. Zhang, Y. Yu, H. Ma, Y. Zhang, and P. Cao, "DeSign of Photovoltaic Power Supply MPPT Circuit for WSN node based on current observation," Int. J. Online Eng., vol. 14, no. 7, pp. 45-61, 2018, https://doi.org/10.3991/ijoe.v14i07.8495

[16] A. Vázquez, C. Gina, and J. Pérez, "View of Photovoltaic system proposal for a house," 2019. https://sciencescholar.us/journal/index.php/ijpse/article/view/330/342 (accessed Jan. 07,2021

[17] R. A. Jalón and E. A. Herrera, "Análisis de eficiencia de un seguidor solar a dos ejes para fines energéticos," Repositorio de la Universidad Estatal de Milagro. 2019, [Online]. Available: http://repositorio.unemi.edu.ec/handle/123456789/4499.

[18] J. Shi and Y. Xu, "Design of solar power management circuit based on wireless sensor network," Int. J. Online Eng., vol. 13, no. 12, pp. 67-75, 2017, https://doi.org/10. 3991/ijoe.v13i12.7891

[19] J. A. Pelayo, A. Luna, F. Bernabe, and B. Guzmán, "Comparativa de la eficiencia entre un sistema fotovoltaico con seguimiento solar y un sistema fotovoltaico fijo / Comparison between a photovoltaic solar tracker efficiency and a fixed photovoltaic system," CIBA Rev. Iberoam. las Ciencias Biológicas y Agropecu., vol. 7, no. 13, pp. 105-129, 2018, https://doi.org/10.23913/ciba.v7i13.76

[20] S. Balaguer, "Seguidor Solar De Dos Ejes," p. 179, 2016, [Online]. Available: http://repositori.uji.es/xmlui/bitstream/handle/10234/165625/TFG_2016_Balaguer

ZuecoSergio.pdf?sequence $=1$.

[21] D. Morelo and S. Puello, "Diseño Y Construcción De Un Seguidor Solar Para Aumentar El Rendimiento Energético En Paneles Fotovoltaicos De Un Sistema De Bombeo," p. 170, 2015, [Online]. Available: https://repositorio.unicordoba.edu.co/bitstream/handle/ucordoba/700/Documento final Seguidor solar correcciones impresion.pdf?sequence $=1 \&$ isAllowed=y. 18687/laccei2015.1.1.024

https://doi.org/10.

[22] A. A. Gaete, "Diseno De Seguidor Solar Fotovoltaico De Dos Ejes De Bajo Costo," p. 129, 2019, [Online]. Available: https://repositorio.usm.cl/handle/11673/49140.

[23] R. Arreola Gómez, A. Quevedo Nolasco, M. Castro Popoca, Á. Bravo Vinaja, and D. Reyes Muñoz, "Diseño, construcción y evaluación de un sistema de seguimiento solar para un panel fotovoltaico," Rev. Mex. Ciencias Agrícolas, vol. 6, no. 8, p. 1715, 2017, https://doi.org/10.29312/remexca.v6i8.490

[24] R. Casimiro, M. Gea, D. Hoyos, and C. Placco, "Seguidor Solar De Dos Ejes Para Helióstato," 2018, [Online]. Available: http://portalderevistas.unsa.edu.ar/ojs/index.php/averma/article/view/1220/1175.

[25] K. Pacco Ramírez, "La energía solar fotovoltaica y sus aplicaciones," p. 161, 2010, [Online]. Available: http://repositorio.utc.edu.ec/bitstream/27000/1346/1/T-UTC-0938.pdf. 
[26] OMS, "Indice Solar," Índice UV Sol. Mund., p. 32, 2003, [Online]. Available: https://apps.who.int/iris/bitstream/handle/10665/42633/9243590073.pdf;jsessionid=341BD5D011C4501C98B362788817D087?sequence=1.

[27] A. Rodas and C. Arévalo, "Dimensionamiento De Una Instalación Fotovoltaica De Generación Distribuida Conectada a La Red, Para Autoconsumo En Un Taller Industrial En guayaquil," p. 83, 2016, [Online]. Available: https://www.dspace.espol.edu.ec/retrieve/97490/D-103473.pdf.

[28] H. Noriega and W. Pereira, "Diseño De Un Sistema Generación De Energía Eléctrica Basado En Paneles Fotovoltaicos Para Mejorar La Eficiencia En áreas Que Utilizan Claraboyas Para iluminación,” p. 283, 2014, [Online]. Available: https://www.dspace.espol.edu.ec/retrieve/101783/D-84474.pdf. https://doi.org/10.22209/mensi.n6a11

[29] W. Lindao, "Propuesta de Diseño de un-Sistema de Energía Solar Fotovoltaica. Caso de Aplicación en Casa Comunal de Cooperativa Los Paracaidistas en la Ciudad de Guayaquil.," J. Chem. Inf. Model., p. 87, 2020, [Online]. Available: http://192.188.52.94/handle/3317/13360\%0A. http://repositorio.ucsg.edu.ec/bitstream/3317/1692/1/T-UCSG-PRETEC-ITEL-29.pdf. https://doi.org/10.14483/23448350.12213

\section{$7 \quad$ Authors}

Washington Garcia Quilachamin. Received the degree of magister in Informatics Management and New Technology in University Technical Federico Santa Maria of Chile (2008), Campus Guayaquil, Ecuador. He is currently pursuing a Ph.D. in System engineering degree with the National University of San Marcos, Lima, Peru. Full-time Professor of computer science in the Faculty of Electric Engineering at the Universidad Laica Eloy Alfaro de Manabí, Ecuador. member of ISOC-Cap.Ec. Research member accredited with REG-INV-18-03232, by the secretary of higher education, science, technology, and innovation (SENESCYT), Ecuador. His research papers have been presented at conferences and published in journals internationally (scopus, springer). Referee of research for national and international scientific journals, conference proceedings. His research activity is related to the Internet of Things, Cloud Computing, intelligence systems, image processing, pattern recognition, control automatic, security, surveillance, and intelligent networks, particularly oriented to management in energy efficiency. Email: profegarcia501@gmail.com

Julieta Evangelina Sánchez Cano. PhD International Economics and Development, Complutense University of Madrid, Spain. Member of the National System of Researchers at CONACYT, México. Professor at the Faculty of Economics, Accounting and Administration of the Universidad Juárez del Estado de Durango from 2009 to date, has taught subjects related to economics and is part of the professors of the $\mathrm{PhD}$ Organization Management in the National Quality Graduate Program of CONACYT. She has been O'Gorman Scholar at ILAS Columbia University, 2013; and Visiting Scholar at ILAS, Columbia University 2015, making research in the topics of Energy. Member at SENESCYT, Prometeo Senior Researcher 2014-2015, Ecuador. She has a long history of applied research in topics of the Energy Sector with more than 60 publications, in books and journals internationally. Email: julieta.san2009@ujed.mx

Jorge Herrera-Tapia. Received the degree in Computer Systems Engineering from the Universidad Técnica de Norte, Ecuador in 1999, and the master's degree in 
Computer and Network Engineering, and Ph.D. degree in Computer Science from the Universitat Politècnica de València (UPV), Spain, in 2015 and 2017, respectively. He is currently a full Professor of Computer Science at the Universidad Laica Eloy Alfaro de Manabí, Ecuador. His research activity is related to green-electric engineering, mobile wireless data systems design, modeling, simulations, and implementations, IoT, particularly oriented to opportunistic wireless networks. Email: jorge.herrera.tapia@gmail.com

Edisson Javier Velesaca-Zambrano. Is currently a student assistant researcher in the Faculty of Electric Engineering at Laica Eloy Alfaro of Manabí University, Manta, Ecuador. Her research activity is related to automation control systems, project management, photovoltaic system and particularly to oriented management in energy efficiency. Email: edissonjvz@gmail.com

Article submitted 2021-02-12. Resubmitted 2021-03-17. Final acceptance 2021-03-18. Final version published as submitted by the authors 